\title{
SOCIALIZATION OF HEALTHY OIL USE IN THE PKK GROUP IN BEKASI
}

\author{
Shanti Pujilestari, Mohammad Sabariman, Kania Ratnasari \\ Universitas Sahid, Indonesia. \\ shanti pujilestari@usahid.ac.id
}

\begin{abstract}
The use of cooking oil is very close to the group of mothers who are members of the PKK in Pondok Surya Mandala, South Bekasi, both at home and from snacks, although the results of the 2017 study showed that the use of catfish pecel traders in Bekasi City is not safe. The solutions offered from this activity are: (1) The holding of active participation in the PKK group; (2) holding socialization activities in the form of counseling on the use of healthy cooking oil; (3) Poster postings regarding the use of healthy cooking oil are held. The method to achieve the objectives is carried out stages: (1) Active participation approach; (2) Counseling with lecture and discussion methods; and (3) Installation of posters in strategic places. The results of the activities show that: (1) An active increase in community participation has been held, with a $75 \%$ attendance rate; (2) The socialization has been carried out by counseling about the use of healthy cooking oil, with an average increase in participant detention of 48.57\%; and (3) Posters have been installed regarding the use of healthy cooking oil around RW halls and around mosques.
\end{abstract}

Keywords: Socialization, Use, Cooking Oil, Healthy, PKK Group

\section{INTRODUCTION}

Bekasi City, which has an area of about $210.49 \mathrm{~km} 2$, is home to commuter lines who work in Jakarta. The population of Bekasi City is 2,803,283 inhabitants living in 12 sub-districts (Bekasi in figures, 2016). The economy in Bekasi is very closely related to cities in the Jabotabek area. The West Bekasi region is an area bordering DKI Jakarta. The existence of adequate transportation facilities from Bekasi to Jakarta has led to the establishment of housing estates and residential areas in Bekasi City, one of which is Pondok Surya Mandala in the South Bekasi District. Pondok Surya Mandala is a housing complex that has been around for a long time, precisely since 1988. This housing consists of $1 \mathrm{RW}$ with $14 \mathrm{RTs}$ with a population of around 850 people. It is estimated that most of the household heads work in Jakarta, even in a family there are fathers and mothers who work in Jakarta and other areas around the City of Bekasi.

The length of the trip due to traffic jams and busyness causes residents at Pondok Surya Mandala to prefer eating outside the house or cooking easy and tasty food. These foods include foods that are processed using cooking oil. In this case the role of cooking oil cannot be released from mothers in all households. The function of cooking oil is ripening by delivering heat, softening and making it tasty / tasty due to the fat content it contains and adding to the calories of fried foods. Cooking oil can be made from various foodstuffs, namely copra, coconut, soybeans, corn kernels, sunflower seeds and olive blossoms. The most widely used oil is palm oil through the milling, refining, fractionation, crystallization and separation processes that produce stearin. Then the degumming and melting process is carried out to separate the oil from the impurities, then the oil enters the bleaching process (Yildiz, 2009). Research on the quality of oil in Bekasi City catfish pecel traders with 34 samples has been conducted in 2017, resulting in oil damage has occurred after being used 1 (one) trade without being replaced, namely with free fatty acid levels of cooking oil 0.63\% which should be 0.3\% (SNI 7709: 2012 standard for the quality of palm cooking oil). It is estimated that there have been 27 frying replications in 1 (one) trade and oil damage is suspected to occur in the 3rd replication.

Other research states that the quality of oil in fried foods (tofu, tempeh, cassava, bakwan, banana and aci goreng) at Pondok Cina Depok shows that the levels of cooking oil-free fatty acids exceed SNI 7709: 2012 after more than 3 (three) repeated frying replications, usage with free fatty acid content of $0.63 \%$ and peroxide number 13.94 mek $\mathrm{O} 2 / \mathrm{kg}$. The interest of housing residents to buy fried food, this is shown by the presence of 15 traders of catfish or other fried pecel in Pondok Surya Mandala which is always exhausted. Repeated use of oil in fried food traders because they want to make a profit, even though traders also know that it is dangerous for health. Oil damage starts from the smell and rancidity, while other signs of damage are increased free fatty acids, changes in refractive index (refractive), peroxide number, carbonyl number, oil viscosity, foam formation, the presence of dirt from spices and from fried material (Mariati, 2006). The results of Rukmini's research (2007) show that repeated use of used cooking oil (used oil) can endanger body health. That is because during heating there will be a process of degradation, oxidation and dehydration of cooking oil. The process can initially form acrolin (causing itching in 
the throat), then the presence of free radicals and toxic toxic compounds. The above description shows that knowledge of the use of healthy cooking oil is very much needed by the mothers in Pondok Surya Mandala, so the partners in this activity are the Family Welfare Development (PKK) group. This activity is also expected to initiate the realization of a healthy lifestyle in the community. Solutions for situation analysis at Pondok Surya Mandala are: (1) holding activities to increase active community participation; (2) holding socialization activities in the form of counseling on the use of healthy cooking oil; (3) Poster postings regarding the use of healthy cooking oil are held.

\section{METHODS}

The method of activities used are: (1) Participatory approach by contacting the family in Pondok Surya Mandala, by coordinating with several mothers who are classified as active in the PKK. This group will be invited to discuss the issue of the use of cooking oil at the household level as well as at fried food sellers in the housing area. This group will participate directly in the planning, implementation and evaluation of activities. In conducting the socialization, the method used is counseling by:

a. Lecture method

The lecture is conducted by way of the resource person providing one-way training material.

b. Discussion method

The discussion is carried out by inviting questions and answers between participants and resource persons related to the material that has been delivered.

After that will be done, (3) Posters of the use of healthy oil in two strategic places. Evaluation of the activities include evaluating the pre-test and post-test of the counseling participants. Counseling was declared successful if there was an increase in the value from pre test to post test. Another assessment is the positive response from the counselors.

\section{RESULTS AND DISCUSSION}

\section{Coordination of planning (place, time and participants)}

This women groups active in PKK activities are also invited to discuss in order to increase wider community participation. The women in the Pondok Surya Mandala environment are very busy and find it difficult to find time to carry out the socialization of the use of healthy cooking oil that will be held. Coordination of Activity Planning can be seen in Picture 1. The meeting for participatory enhancement was held when the PKK group was going to do morning gymnastics on Saturday. This is done so that the women do not need to take other time for the meeting. The results of the coordination also determine the location, time and participants of the activity. The location of the activity was determined at Balai RW 13 Pondok Surya Mandala. RW 13 has a RW hall located in the middle of a housing complex. Almost all RW activities are carried out at the RW Hall, for example gymnastics, RW social gathering, independence day events and other events at the RW level. When the activity is planned for Saturday, September 29, 2018. In determining the day of implementation there are many difficulties because many women may not be able to attend due to the busy schedule of both the invitation and other activities. Participants in PKK Rukun Warga (RW) group, it is known that in Pondok Surya Mandala there is only 1 RW, namely RW 13. The number of RTs that are under the coordination of RW 13 is 14 RT. Each RT has its own PKK organization, so it is expected that coordination for the dissemination of healthy oil can be carried out easily. It was also decided that each RT would send 2 representatives as participants. So if there are 14 RTs, it is expected that there will be 28 people present at the outreach activities. From 2 RT representative women, it is expected to be able to socialize the material given back to their respective RT residents so that the information provided can be distributed to all women in Pondok Surya Mandala.

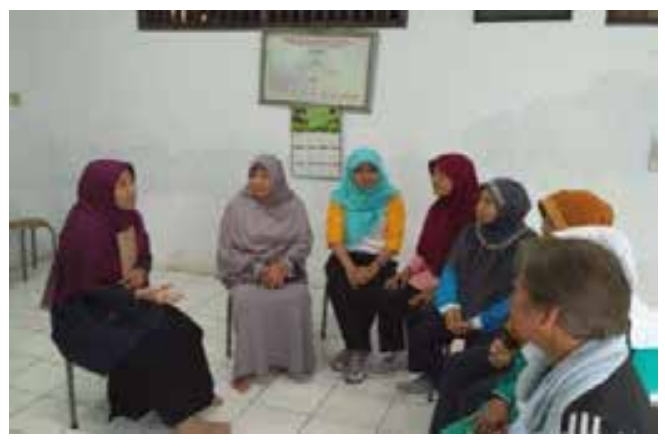

Picture 1. Coordination of activity planning 


\section{Develop a joint plan for training materials}

In the process of this discussion the focus is addressed on the issue of why this activity should be carried out and the material to be delivered. In conveying the background of why the material for the use of healthy cooking oil is important to be known by the women at Pondok Surya Mandala, then finally this activity was agreed. The material on the use of healthy oils was agreed as the subject matter. While the results of cooking oil research in catfish pecel traders in Bekasi and similar studies will complement the counseling material. From the discussion obtained information that many mothers who already understand the use of healthy cooking oil, only the implementation is rather difficult. However, to remind again the importance of using healthy cooking oil at the household level so as to increase awareness and facilitate implementation in the household and when buying food at the merchant.

\section{Counseling}

In the implementation of outreach, counseling is done by lecturing and discussion methods. The resource person has presented material on the use of healthy oil which is supplemented by the results of research into the use of cooking oil in catfish pecel traders in Bekasi as well as other related research. Before the material is given, participants are asked to do a pre-test, although it seems that there are many who are not ready to do the pre-test but still the participants can do everything they can. Lecture delivery of material went smoothly and well using the LCD. Before the material is given, participants are asked to do a post test. The discussion carried out went smoothly. Discussions are held with participants asking questions to resource persons related to the material that has been submitted. There were two participants who asked questions. In accordance with the counseling plan, it is carried out at Balai RW. Balai RW can be seen in Picture 2.

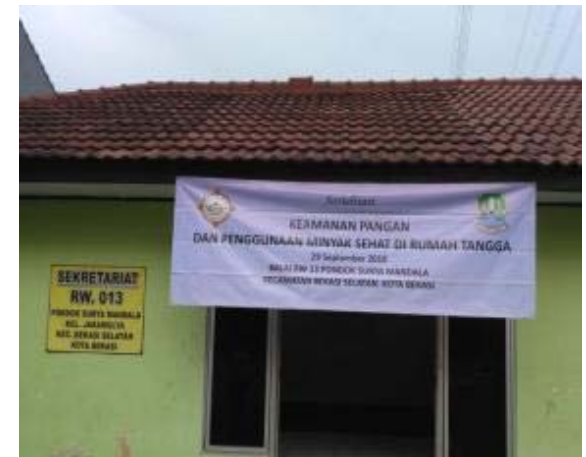

(a)

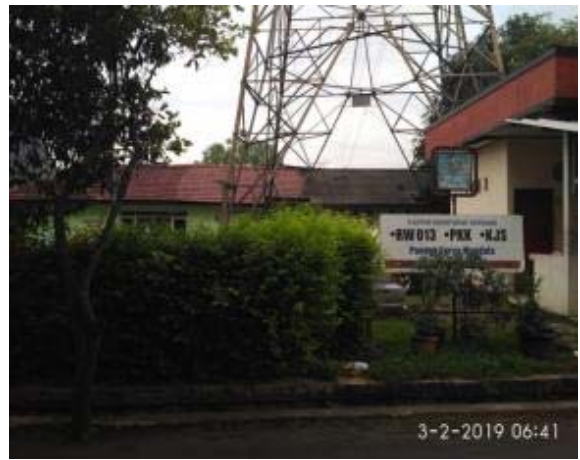

(b)

Picture 2. Balai RW: (a) Front view of Balai RW and (b) front yard of Balai RW

Submission of material from speakers about the use of healthy cooking oil is done casually but remains seriously assisted by LCD Projector (Picture 3). All participants listened carefully by paying attention to the LCD or while reading the material that had been distributed.
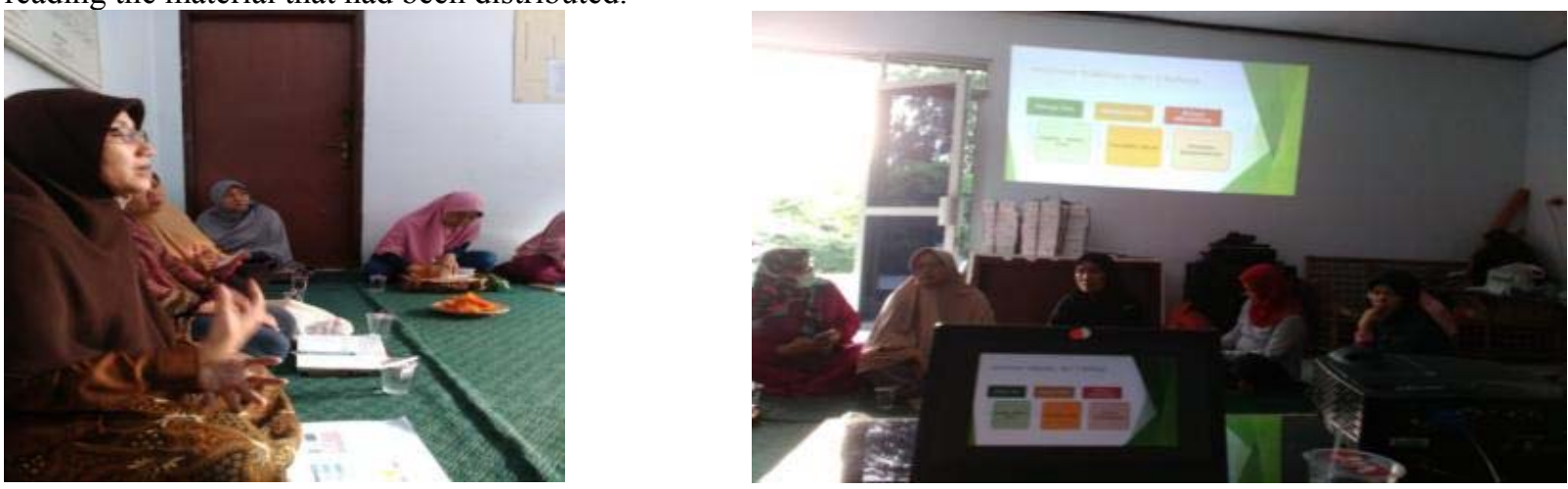

Picture 3. Submission of material

From the discussion also obtained information that many mothers who already understand the use of healthy cooking oil, only the implementation is rather difficult. However, to remind again the importance of using healthy cooking oil at the household level so as to increase awareness and facilitate implementation in the household and when buying food that uses oil. The atmosphere of increased understanding and discussion can be seen in Picture 4. 

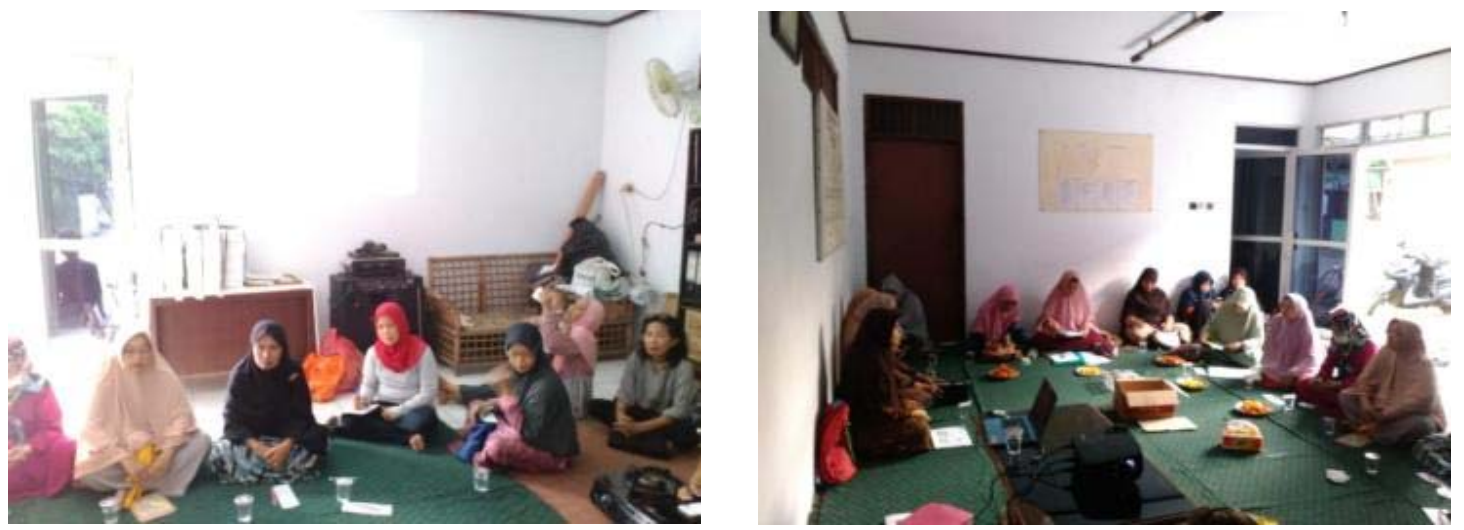

Picture 4. Discussion atmosphere

In the discussion also discussed the use of cooking oil in traders too often have been heard, but in practice it is very difficult not to buy fried food at the merchant. The answer to this question is the same as in the previous answer that what causes oil to damage. How fried food sellers use cooking oil. We should indeed manage our own food at home. If forced to do so the best way is to become the first buyer because cooking oil is still being used at that time.

\section{Poster installation}

The poster for the use of healthy oils was carried out to remind present participants of the information about the material that had been given. For mothers who were absent, they could see the material briefly from the poster. It is expected that there has been a transfer of knowledge from the counselors to all mothers in Pondok Surya Mandala. Poster for the use of healthy cooking oil can be seen in Picture 5.

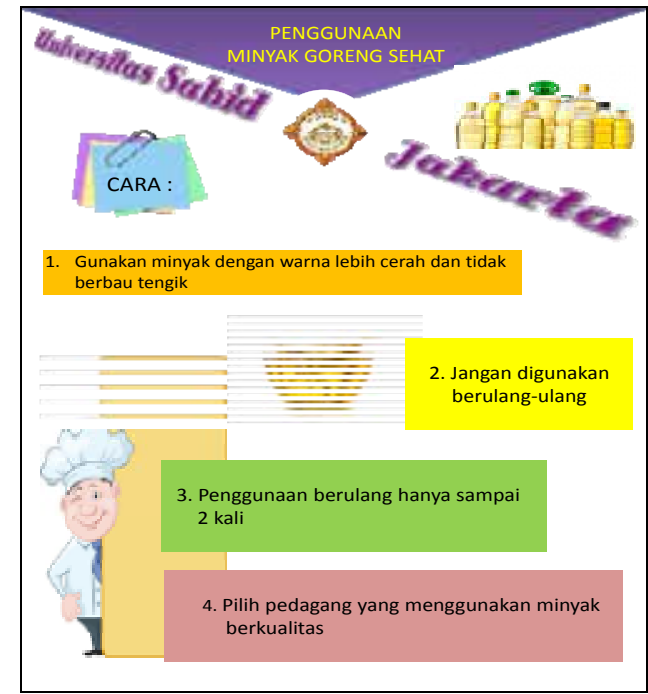

Picture 5. Poster of the use of healthy cooking oil

Healthy oil usage poster consists of 4 messages, namely: (1) Use oil with a brighter color and not smell rancid; (2) Don't use it repeatedly; (3) Repeated use only up to 2 times; and (4) Select traders who use quality oil. On this poster there is also the Jakarta Sahid University logo to introduce Sahid University as an institution that also cares about the environment. Poster installation was carried out in two strategic places, namely around the RW Hall and mosque. It aims to be seen by many people, so that they can be read and increase knowledge and recall. Installation of posters is done in strategic places around the Balai RW and mosque. The location of poster installation can be seen in Picture 6 . 


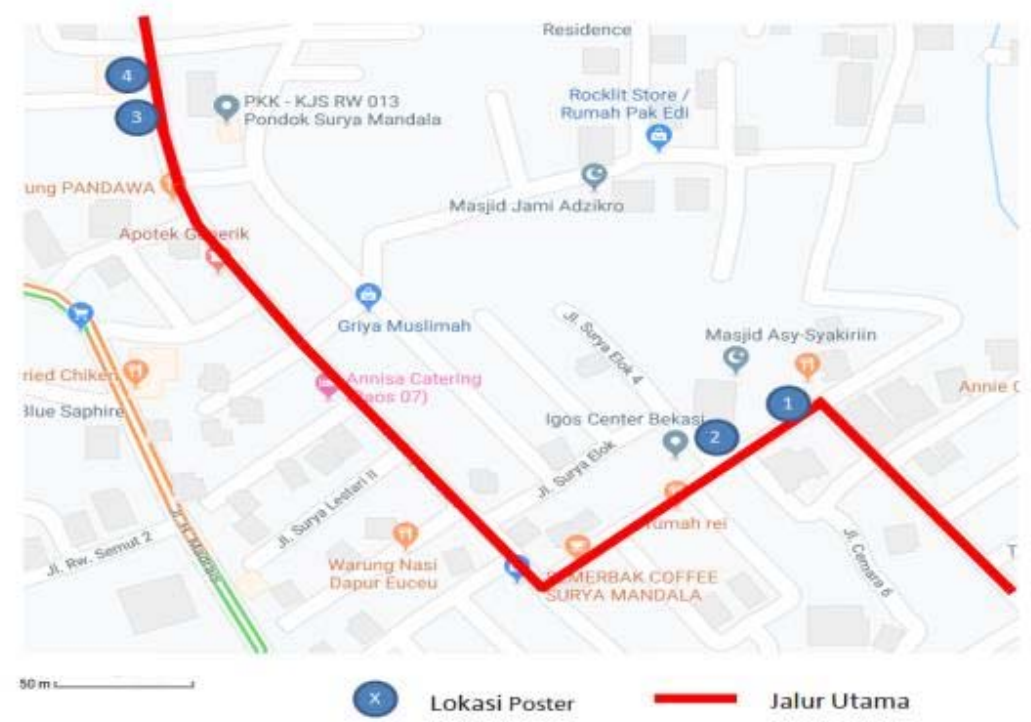

Picture 6. Poster installation location

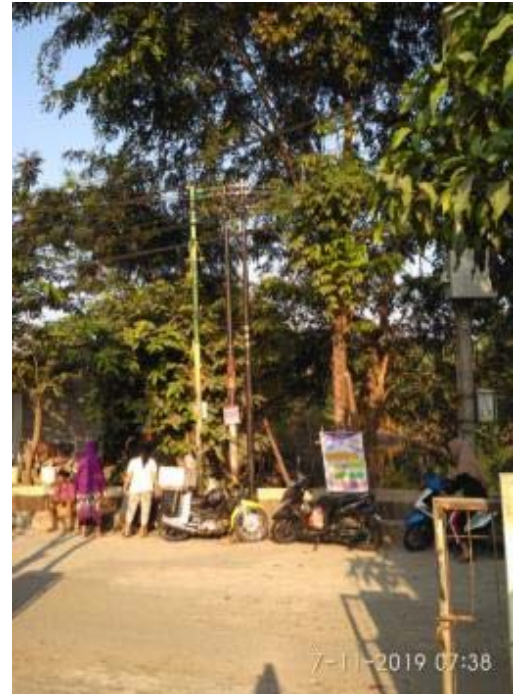

Picture 7. Poster installation photo around Balai RW

Picture 6 shows that the poster for healthy oil use is on the side of the road around Balai RW and Asy Syakirin Mosque (blue 1 and 2). The distance between Balai RW and Asy Syakirin Mosque is 350-400 m. Posters around the Balai RW can be seen in Picture 7. Picture 7 shows the poster that has been installed around the RW hall. This aims to be seen by many people, because around the Balai RW gathered vegetable traders, fishers, stalls and other traders, so that in that place many mothers gather to shop. It is hoped that the poster can be read and add to knowledge and recall. Posters around Asy Syakirin Mosque can be seen in Picture 8 . 


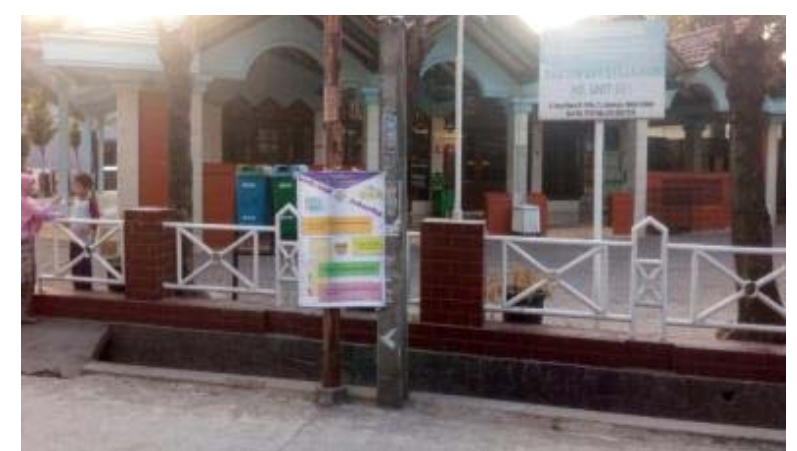

Picture 8. Poster around the Asy Syakirin Mosque

Picture 8 shows that posters can be seen around the As Asirinirin mosque. Asy Syakirin Mosque is in the middle of Pondok Surya Mandala Housing. Seen from across the road in front of the mosque, a poster for the use of healthy oil was installed on the side of the road around the mosque asy syakirin. Installation in the mosque because many people are passing by to the mosque so it is expected to be seen by mothers or other community groups.

From the number of participants who were present as many as 21 people from the target of 28 people (75\%). This is allegedly due to the busy mothers with their respective families, because the day of the implementation of counseling is a holiday. Direct evaluation is carried out on the pre-test and post-test results in counseling activities. From these results it was found that the pre-test and post-test results increased by $48.57 \%$. This shows that your knowledge about the use of healthy oils in Pondok Surya Mandala increased from before the extension was carried out. From the final discussion with the PKK group it was stated that the counseling activities were very good for the mothers at Pondok Surya Mandala to gain knowledge and all participants were happy to get new knowledge. The next hope is that all participants can share their knowledge with other mothers in their respective RT neighborhoods. It is also expected to be able to implement it in everyday life so that this activity can initiate a healthy life. Poster installation has been carried out in two strategic places, namely around the Balai RW and Mosque. The message of using healthy oils is expected to be inherent in the community.

\section{CONCLUSION}

From the activities carried out, the conclusions of the activity are:

1. Increased active participation with a $75 \%$ attendance rate

2. Increased knowledge about the use of healthy cooking oil increased by $48.57 \%$

3. Posters have been installed on the use of healthy oil around the Balai RW and Asy Syakirin Mosque

\section{ACKNOWLEDGEMENT}

Thank you to Sahid University through the Research and Community Service Institute (LPPM), which has funded this activity through the Internal Community Service Fund.

\section{REFERENCES}

Badan Pusat Statistik Kota Bekasi. (2016). Kota Bekasi dalam Angka 2016. ISBN:1907:3763.

Badan Standarisasi Nasional (BSN). (2012). SNI 7709:2012 : Mutu Minyak Goreng Sawit.

Mairah. (2017). Studi Kualitas Minyak Goreng yang digunakan Pedagang Pecel Lele di Kota Bekasi. Skripsi. Universitas Sahid Jakarta.

Mariati, K. (2006). Pengaruh frekuensi Penggorengan dan Perendaman Kulit Pisang Kepok terhadap Penurunan Bilangan Peroksida Minyak Kelapa Sawit Sisa Pakai. Skripsi. Universitas Negri Semarang.

Rukmini, A. (2007). Regenerasi Minyak Goreng Bekas dengan Arang Sekam Menekan Kerusakan Organ Tubuh. Jurnal Teknologi Pertanian. ISSN 1978-9777. Universitas Widya Mataram. Yogjakarta.

Uli SR. (2016). Studi Kadar ASam Lemak Bebas dan Bilangan Peroksida dalam Minyak Goreng pada Jajanan Gorengan di Wilayah Kelurahan Pondok Cina Depok.Skripsi. Universitas Sahid Jakarta.

Yildiz. (2009). Advance in Food Biochemistry. CRC press. Boca Raton. 